\title{
UPAYA MENGURANGI SKEPTISISME IKLAN HIJAU DALAM MENINGKATKAN PERILAKU PEMBELIAN PRODUK HIJAU
}

\author{
Jati Waskito dan Wahyono \\ Email: Jw271@ums.ac.id \\ Dosen tetap FEB UMS, Jl. A Yani Tromol Pos 1 Surakarta
}

\begin{abstract}
The purpose of this study was to analyze the effect of consumer involvement in environmental sustainability, relevance, confusion, and entertainment from an ad impression of green against the skepticism of consumers through an approach of how far the company can deliver their messages more effectively. Survey by the instrument list of questions to get 299 residents of the city of Solo who participated in the study. The results of multiple regression analysis found that consumer involvement and relevance negative effect on consumer apathy towards green advertising. Variable confusion positive effect on consumer apathy towards green advertising. While variable entertain no significant effect on their skepticism.
\end{abstract}

Kata kunci: consumer involvement, relevance, confusion, entertain, skeptical

\begin{abstract}
Abstrak:
Tujuan dari penelitian ini adalah untuk menganalisis pengaruh keterlibatan konsumen dalam kelestarian lingkungan, dan tayangan iklan hijau yang memiliki tema relevan, membingungkan dan bersifat menghibur, terhadap skeptisisme mereka. Studi ini membuat pendekatan dari seberapa jauh perusahaan dapat menyampaikan pesan hijau mereka secara lebih efektif. Survei dilakukan dengan instrumen pertanyaan. 299 penduduk kota Solo bersedia ikut berpartisipasi dalam studi. Semua variable diukur dengan mengadopsi dari penelitian sebelumnya. Hasil analisis regresi berganda menemukan bahwa keterlibatan konsumen dan relevansi berdampak negatif psecara signifikan pada apatis konsumen terhadap iklan hijau. Variabel kebingungan berpengaruh positif pada sikap apatis konsumen terhadap iklan hijau. Sedangkan variabel menghibur tidak berpengaruh signifikan terhadap skeptisisme mereka.
\end{abstract}

Kata kuci: keterlibatan konsumen, relevansi, kebingungan, hiburan, dan sikap skeptis

\section{LATAR BELAKANG}

Masalah lingkungan telah menjadi isu penting di dunia industri dan akademisi selama lebih dari 30 tahun. Isu lingkungan juga memiliki implikasi strategis bagi perusahaan. Sebagai contoh, Albayrak et al. (2011) menyatakan bahwa kesadaran lingkungan saat ini sangat terlihat jelas di industri. Seolah perusahaan-perusahaan mulai berlomba untuk menunjukkan bahwa produk mereka lebih hijau. Hal ini untuk menjawab meningkatnya kekhawatiran konsumen tentang pada penurunan kualitas lingkungan dalam beberapa tahun terakhir. Dengan meningkatnya jumlah pelanggan "hijau", dunia bisnis berusaha untuk memahami dan menanggapi tekanan eksternal untuk meningkatkan kinerja lingkungan mereka (Chen dan Chang, 2012).
Sejumlah perusahaan menunjukkan sensitivitas lingkungan mereka dengan strategi yang berbeda. Salah satu alat pemasaran yang digunakan oleh organisasi adalah iklan hijau. Iklan hijau pertama dimulai pada 1970 ketika resesi yang menyebabkan harga minyak setinggi langit. Sementara upaya pemasaran dan periklanan hijau terus tumbuh, pemasar tidak memiliki alat yang memadai untuk mengevaluasi keberhasilan iklan hijau (Kuhro, et al., 2015).

Iklan saat ini menjadi bagian yang kuat dan tak terpisahkan, bahkan seolah menjelma menjadi salah satu bagian dalam kehidupan dan kita tidak mungkin terlepas darinya. Berniat untuk melihatnya maupun tidak, iklan tetap suatu saat ada dihadapan dan harus ditonton. Sampai akhirnya iklan menjadi informasi yang paling akrab dan mampu mewarnai memori mulai dari masa kanak-kanak dan 
mungkin akan selalu diingat sampai orang tersebut dewasa. Sering kali beberapa iklan dianggap dangkal, mengelabui, merangsang, dan mengundang hasrat. Sementara ada juga yang dinilai jenaka, atraktif, menghibur, mempesona dan menghanyutkan. Ada juga iklan yang membawa isu krusial dan mencoba menyadarkan khalayak berkaitan dengan pentingnya isu tersebut (Albayrak et al., 2011). Misalnya iklan hijau, yang berusaha membuka kesadaran masyarakat tentang pentingnya kelestarian lingkungan.

Pemasar pasti menghendaki pesan yang akan mereka sampaikan dalam iklan itu relevan (relevance), tidak membingungkan (confuse), dan ada unsurmenghibur(entertain). Harapannya adalah tiga pilar utama dalam pesan iklan tersebut dapat mengurangi sikap skeptis masyarakat yang pada ujungnya dapat menggerakkan mereka untuk membeli. Dengan demikian hal ini dapat mengamankan sejumlah besar dana perusahaan sehingga tidak hilang secara percuma. Lebih dari itu perusahaan dapat mengkomunikasikan pesan mereka secara lebih efektif (Kuhro, et al., 2015).

Penelitian yang berkaitan dengan sikap skeptisisme terhadap iklan telah banyak dilakukan. Studi ini mencoba untuk mempelajari pengaruh skeptisisme terhadap perilaku pembelian hijau. Para peneliti telah memperkirakan bahwa secara keseluruhan, lebih dari \$ 16 milyar telah dihabiskan untuk pemasaran dan periklanan (Research, 2011). Apabila iklan tidak efektif dan target pasar lebih cenderung ke arah skeptisisme, maka dapat dibayangkan berapa banyak uang yang terbuang percuma.

Sebagian besar konsumen menganggap diri mereka sebagai individu yang peka terhadap lingkungan, banyak penelitian tidak menunjukkan hasil yang konsisten antara klaim konsumen tsb.dengan perilaku pembelian mereka. Sebagai contoh, di Inggris ada kesenjangan yang signifikan antara kesadaran lingkungan dan perilaku (Thompson \& Tian, 2008). Konsumen, meskipun memiliki sikap yang mendukung terhadap makanan organik (antara 46-67\%), hanya $4-10 \%$ benar-benar membeli barangbarang tersebut, dan kecenderungan ini telah berlangsung selama 3 tahun terakhir. Hasil serupa telah ditetapkan oleh penelitian yang dilakukan di Amerika Serikat meskipun dipertimbangkan bahwa penelitian lebih lanjut diperlukan untuk mengkonfirmasi hubungan sikap dan perilaku. Penelitian Waskito dan Sujadi (2013) juga menemukan hal yang sama bahwa tingkat kesadaran konsumen terhadap lingkungan sudah tumbuh tetapi belum pada tahapan action, yakni pembelian produk hijau.

Penelitian ini menguji model pembentukan tema iklan yang tepat untuk mengurangi sikap skeptis konsumen terhadap iklan hijau. Secara terinci adalah sbb.:

1. Menguji pengaruh keterlibatan konsumen dengan lingkungan (consumer involvement) terhadap sikap skeptis mereka pada iklah hijau

2. Menguji pengaruh tingkat kebingungan (confuse) konsumen pada pesan sebuah iklan terhadap sikap skeptis mereka

3. Menguji pengaruh negatif tema iklan yang releven dengan kebutuhan konsumen terhadap sikap skeptis

4. Menguji pengaruh negatif tema iklan yang menghibur terhadap sikap skeptis konsumen

\section{TINJAUAN PUSTAKA DAN HIPOTESIS}

\section{Skeptisisme}

Skeptisisme didefinisikan sebagai kecenderungan ketidakpercayaan terhadap klaim iklan (Obermiller \& Eric, 1998). Konsumen dapat bervariasi dalam skeptisisme terhadap iklandi berbagai media yang berbeda, misalnya iklan cetak, iklan radio dan iklan televisi. Seseorang mungkin skeptis terhadap klaim kebenaran dalam sebuah iklan disebabkan oleh motif pengiklan. Informasi yang diberikan mungkin kurang mempertimbangkan kesesuaian individu atau masyarakat, sebagai audiens target, misalnya perbedaan latar belakang budaya masyarakat. Skeptisisme iklan dapat bervariasi mulai dari sikapkonsumen skeptis rendah sd. konsumen skeptis tinggi. Selanjutnya, Obermiller, C., \& Eric, RS (1998) telah memberikan klarifikasi bahwa skeptisisme iklan tidak berarti bahwa tidak percaya pada setiap komunikasi, namun mereka telah menempatkankandungan isi pesan iklan itu dalam benak mereka yang terbentuk melalui seringya sosialisasi pada 
pesan yang sama atau pengalaman konsumen.

Skeptisisme menciptakan banyak permasalahan, demikian pula bagi konsumen hijau yang cenderung dikenal sebagai konsumen yang lebih berpendidikan, berusia muda dan penduduk perkotaan (Kuhro et al., 2015). Hasil penelitian menemukan bahwa ada hubungan negatif antara konsumen hijau dan kenyataan yang tidak menyenangkan dari sebuah iklan. Banyak kenyataan yang terjadi secara empiris bahwa adanya kerusakan lingkungan sebagai akibat dari klaim hijau perusahaan yang salah (Waskito \& Sujadi, 2013). Hal ini menyebabkan kredibilitas produk dan perusahaan menurun dan konsumen hijau menjadi tidak percaya lagi untuk mengkonsumsi produk hijau. Keadaan ini pada akhirnya dapat menyebabkan kerusakan lingkungan fisik dan akan berdampak pada manusia.

Obermiller et al., (2005) dalam penelitiannya menyatakan bahwa ada banyak produk mengalami permasalahan mulai dari skeptisisme iklan yang rendah sd.sebuah produk terpengaruh secara negatif karena skeptisisme yang lebih tinggi. Sementara dalam studi kedua, ia menunjukkan bahwa skeptis tinggi lebih banyak munculyang disebabkan olehinformasi iklan daripada sikap emosional pelanggan.

\section{Consumer Involvement}

Pengertian keterlibatan menurut Solomon (2009:163) adalah:" Involvement is a person's perceived relevance of the object based ontheir inherent needs, values, and interests". Objek yang dimaksud disini dapat berarti suatu produk (atau merek), iklan, maupun situasi pembelian.Menurut Rothschild ( dalamKapferer dan Laurent, 1986:49):

Involvement is an unobservable state of motivation, arousal or interest.It is evoked by a particular stimulus or situation and has drive properties.Its consequences are types of searching, informationprocessing anddecision-making

Maksudnya keterlibatan merupakan suatu keadaan motivasi, gairah atau minat yang tidak tampak.Hal ini ditimbulkan oleh stimulus atau situasi tertentu danmemiliki sifat penggerak. Konsekuensinya adalah jenis pencarian, pengolahan informasi dan pengambilan keputusan.Pengertian keterlibatan menurut Engel, Blackwell, dan Miniard (1994) adalah merupakan refleksi dari motivasi yang kuat di dalam bentuk relevansi pribadi yang sangat dirasakan dari suatu produk atau jasa didalam konteks tertentu.Keterlibatan dapat menunjukkan seberapa besar termotivasinya kita untuk memproses informasi.Dengan semakin meningkatnya keterlibatan, konsumen memiliki motivasi yang lebih besar untuk memperhatikan, memahami, dan mengelaborasi informasi tentang pembelian (Mostafa, 2007).

Solomon (2009) mengutarakan bahwa pada saat anda merasa mengetahui tentang suatu produk akan membantu anda untuk mencapai suatu tujuan, dan anda termotivasi untuk memperhatikan informasi mengenai hal tersebut. Beberapa riset mengatakan bahwa ada banyak tipe keterlibatan untuk menerangkan sikap dan behavior intentions konsumen terhadap iklan dan mereka yang diiklankan (Li,2010) Faktor keterlibatan konsumen memiliki pengaruh langsung maupun tidak langsung pada sikap terhadap iklan. Misalnya, Moore et al. (2000) berpendapat bahwa keterlibatan pengetahuan kelas produk memiliki pengaruh langsung terhadap penerimaan pesan iklan seperti yang dikutip dariLi (2010). Peneliti setuju bahwa keterlibatan iklan memiliki pengaruh langsung pada tanggapan iklan individu.Misalnya, para peneliti berpendapat bahwa individu dengan keterlibatan lingkungan yang tinggi memiliki kepercayaan yang tinggi terhadapmerek yang diiklankan, serta memiliki kemampuan mengingat kembali informasiyang diiklankan. Hasil penelitian yang menguatkan penelitian sebelumnya yang dilakukan oleh D'Sauza (2007) bahwa individu dengan keterlibatan tinggi akan bersikap positif terhadap iklan hijau, sementara yang keterlibatannya randah akan semakin meningkatkan sikap skeptis mereka.

H1: Semakin tinggi keterlibatan konsumen terhadap lingkungan semakin dapat menekan sikap skeptis mereka terhadap iklan hijau 


\section{Relevansi}

Kegiatan iklan dengan misi tertentu biasanya oleh khalayak cenderung dianggap lebih relevan daripada sekedar mengiklankan produk. Dalam hal ini relevansi berarti seberapa baik tayangan iklan tersebut mewakili dengan target pesan yang ingin disampaikan (Sala et al. , 2007). Pemilihan terminologi yang tepat dapat membuat dampak yang lebih baik pada iklan ketika tingkat pengetahuan konsumen tinggi. Bahkan pilihan terminologi ini menjadi simbol untuk keaslian dan keberhasilan dalam tayangan iklan. Ketertarikan konsumen karena bahasa yang tepat ini pada saatnya akan dapat meningkatkan relevansi dalam pesan iklan dan mengurangi sikap skeptis mereka (Chuang, Tsai, Cheng, \& Sun, 2009).

Konsumen menonton iklan dan pemasar mencoba untuk merangsang perasaan mereka. Dalam hal ini perasaan yang dianggap sebagai representasi dari target iklan, dan perasaan inilah yang akan dievaluasi berdasarkan relevansi pesan dalam iklan. Apabila target iklan adalah individu yang berpendidikan, relevansi pesan iklan harus ditingkatkan sehingga akan membuat konsentrasi individual yang lebih besar dalam menangkap pesan (Pham 1998).

Konsumen dengan pengetahuan yang tinggi dapat menilai relevansi produk atau jasa dengan kebutuhan dan keinginan mereka. Apabila terjadi kesalahan informasi yang dilakukan oleh pemasar dalam penyampaian pesan iklan, dapat menyebabkan ketidakpercayaan konsumen (Cowley \& Janus, 2004). Bila pesan memiliki relevansi dengan keinginan atau kebutuhan pribadi mereka, konsumen akan menaruh perhatian yang lebih besar pada pesan tersebut, namun pada saat yang sama jika lalulintas pesan sangat tinggi (overload) dan kurang menyentuh dengan kebutuhan pribadi mereka, dapat mengakibatkan dampak negatif pada iklan (Wang \& Calder, 2006).

H2: Relevansi menciptakan kepercayaan dalam iklan; kepercayaan tentang iklan akan meminimalkan sikap skeptisisme.

\section{Kebingungan}

Kebingungan konsumen berkaitan dengan penayangan iklan dapat berasal dari tiga sumberutama:1. Pilihan produk yang terlalu banyak; 2.Kesamaan produk; dan/ atau; 3.Informasi yang ambigu, menyesatkan atau tidak lengkap yang disampaikanmelalui komunikasi pemasaran (kesimpangsiuran/ ketidakjelasan produk).

Dalam proses periklanan, variabel ambiguitas menjadi hal yang penting. Kuhro et al. (2015) telah membahas bahwa sosiopsikologis adalah faktor yang memotivasi pemirsa televisi untuk melihat iklan. Kebingungan dapat berasal dari merek dagang ketika merek yang diiklankan; kebingungan initerjadi atas dasar asosiasi. Asosiasi dibagi dalam tiga kategori, kebingungan langsung, kebingungan tidak langsung, atau kebingungan murni (Li, 2010). Kebingungan mungkin datang dari susunan kata yang dipilih dalam penyampaian pesan iklan (LeBlanc \& Muise, 1985). Terminologi juga dapat menciptakan kebingungan dalam iklan, biasanya terjadi ketika pengakuan produk (akreditasi) ditampilkan dalam iklan (Brinkmann, Czaske, \& Bosch, 2003). Sertifikasi yang berkaitan dengan kandunganbahan baku produk dan akreditasi bahan yang dikeluarkan produsen. Kebingungan konseptual sering merasuki pemikiran dan mendorong over-generalisasi. Hal ini dapat menjadikankonsumen menjadi lebih menyederhanakan suatu informasi (LeBlanc \& Muise, 1985).

H3: Kebingungan menciptakan ketidakjelasan dalam iklan, yang kemudian memperkuat skeptisisme.

\section{Hiburan}

Entertainment mengacu pada bagaimana konten dalam iklan dapat memenuhi kebutuhan konsumen akan hiburan, kenikmatan estetika dan pelepasan emosional (Ozkocak,2011). Kesenangan dihubungkan dengan periklanan yang memainkan peranan yangsangat besar bagi seluruh sikap mereka terhadap iklan (Thompson \& Tian, 2008).Entertainment dapat meningkatkan loyalitas konsumen dannilai tambah bagikonsumen.

Emosi seseorang adalah bagian yang pasti ada dari perilaku dan kemampuan kognitif. Para peneliti mengaitkan emosi dengan pengambilan keputusan. Mereka menemukan bahwa emosi membantu untuk memahami suatu pesan. Ada lima emosi 
utama, pertama, kemarahan, kedua, ketakutan, ketiga, jijik, keempat, kebahagiaan, kelima, kesedihan. Pemicu emosiditayangkan kepada pemirsa untuk hiburan (Salem \& Rauterberg, 2005).

Dalam iklan populer, seruan/ajakan digunakan untuk memberikan rasa tertentu pada pelanggan. Ketika pemasar berniat untuk menangkap pasar umum yang lebihbesar, dalam hal ini, tema hiburan digunakan untuk pelanggan biasa. Sementara itu cita rasa seni dan kompleksitas yang lebih tinggi digunakan untuk pelanggan profesional yang memiliki daya fikir yang kritis(Kuhro, et al.,2015).

Suatu kenyataan yang harus dipertimbangkan para pemasar adalah bahwa penikmat iklan adalah di kalangan anakanak. Mereka biasanya mendapatkan pesan iklan dalam bentuk hiburan. Anak-anak terutama yang sudah bisa berfikir, terbukti lebih tertarik dengan pesan iklan konsumsi dalam bentuk hiburan. Namun demikian, hal ini juga dapat menyebabkan ancaman bahwa iklan dipandang hanya sebagai penciptaan gambar dan kurang fokus pada produk itu sendiri (Moore \& Lutz, 2000). Artinya iklan bisa menghibur tetapi pesan belum tentu dapat mereka pahami seutuhnya.

Menurut Thompson \& Tian (2008), mitologi iklan mengandung hiburan dalam berbagai bentuk hiburan yang digunakan oleh pemasar seperti konser, olahraga, drum, film, dan narasi. Pemasar fokus pada pesan bertema hiburan sehingga konsumen lebih banyak mendapatkan iklan dengan tema hiburan ini. Di Amerika 8,5 persen dari total pendapatan mereka dihabiskan untuk iklan dengan tema hiburan (Salem \& Rauterberg, 2005).

H4: Semakin banyak tema hiburan dalam iklan akan mengurangi skeptisisme

\section{METODE PENELITIAN}

\section{Data yang diperlukan}

Data primer yang diperlukan dalam penelitian ini terbagi atas dua bagian. Pertama, data yang meliputi karakteristik responden terdiri dari usia, jenis kelamin, pendidikan dan pekerjaan. Kedua, data mengenai persepsi responden terhadap limavariabel penelitian yang menjadi obyek penelitian (consumer involvement, confusion, entertain, relevance, dan skeptise)

\section{Metoda Pengumpulan Data}

Metode survey dengan instrumen daftar pertanyaan, dilakukan terlebih dahulu uji coba pendahuluan kepada 20 orang yang memiliki pengalaman membeli dan yang belum pernah membeli produk hijau.Mereka diminta untuk mengisi kuesionerdan mengidentifikasi apabila terdapat ketidakjelasan istilah, makna, dan isu-isu yang ditampilkan dalam kuesioner.Setelah diperbaiki dilakukan lagi pengujian yang kedua untuk lebih menjamin bahwa responden paham benar untuk mengisi kuesioner. Dengan cara seperti ini, kuesioner diharapkan memiliki tingkat validitas konten yang tinggi.Validitas isi yang tinggi diperlukan untuk survei kuesioner dalam penelitian ini.

\section{Metoda Pengambilan Sampel}

Populasi dari penelitian ini adalah warga kota Solo. Sampel diambil dengan menggunakan metode multi stage sampling, yaitu dengan mempertimbangkan keseimbangan tempat responden di lima kecamatan di Kodya Surakarta. Sampel yang dipilih juga mempertimbangkan keseimbangan karakteristik pribadi mereka seperti umur, jenis kelamin, pendidikan, pekerjaan, dan pengalaman mereka dalam membeli produk hijau.Hasil survey mendapatkan 299 orang yang bersedia menjadi responden.

\section{Variabel Penelitian dan Pengukuran}

Definisi dan pengukuran konstruksi dalam penelitian ini adalahsebagai berikut, untuk variabel Skeptisisme, Relevance, Entertain, dan Confuse menggunakaninstrumen yang sama digunakan oleh Obermiller \& Eric (1998) dan Lastovicka (1983). Kedua studi mereka telah mempelajari pengaruh variabel pada perilaku konsumen. Studi Obermiller \& Eric (1998) hanya mengembangkan skala untuk mengukur skeptisisme konsumen dalam iklan sementara studi Lastovicka (1983) telah difokuskan pada reaksi pemirsa untuk variabel relevance, entertain dan confuse pada iklan televisi. Penelitian ini menggabungkan kedua instrumen tersebut dan mencoba untuk menganalisis pengaruh relevansi, kebingungan, hiburan pada perilaku konsumen 
dan pengaruh faktor-faktor dalam skeptisisme dalam iklan.Pengukuran variabel consumer involvement menggunakan Schuwerk dan Lekoff-Hagius (1995). Skala Likert akan dipakai mulai angkal menunjukkan sangat tidak setuju sd angka 7 menunjukkan sangat setuju.

\section{Analisis data}

Analisis data terdiri dari dua tahap:(1) analisis faktor konfirmatori (CFA) untuk mengevaluasi model pengukuran variabel penelitian, validitas, dan reliabilitas; (2) analisis regresi berganda untuk menguji H1H4 yang memprediksi pengaruh consumer involvement, confusion, entertain, dan relevance terhadap skeptisisme. Selain untuk membangun keandalan dari CFA, konsistensi internal dari skala multi-item dinilai menggunakan perkiraan alpha Cronbach.Hasil analisis faktor ditunjukkan pada tabel 1 .

Tabel 1. Hasil Analisis Faktor

\begin{tabular}{|c|c|c|c|c|c|}
\hline & \multicolumn{5}{|c|}{ Component } \\
\hline & 1 & 2 & 3 & 4 & 5 \\
\hline Involvement 1 & & & .833 & & \\
\hline Involvement2 & & & .823 & & \\
\hline involvement3 & & & .818 & & \\
\hline involvement4 & & & .756 & & \\
\hline relevance1 & & .796 & & & \\
\hline relevance2 & & .802 & & & \\
\hline relevance 3 & & .816 & & & \\
\hline relevance4 & & .807 & & & \\
\hline relevance5 & & .873 & & & \\
\hline confusion1 & & & & & .529 \\
\hline confusion2 & & & & & .571 \\
\hline confusion3 & & & & & .705 \\
\hline skeptis1 & .777 & & & & \\
\hline skeptis2 & .803 & & & & \\
\hline skeptis3 & .857 & & & & \\
\hline skpetis4 & .833 & & & & \\
\hline skeptis5 & .754 & & & & \\
\hline skeptis6 & .780 & & & & \\
\hline skeptis7 & .770 & & & & \\
\hline entertain 1 & & & & .716 & \\
\hline entertain2 & & & & .905 & \\
\hline entertain3 & & & & .885 & \\
\hline $\begin{array}{l}\text { Extraction Met } \\
\text { Rotation Metho }\end{array}$ & $\begin{array}{l}\text { Princi } \\
\text { Varima }\end{array}$ & $\begin{array}{l}\text { ompon } \\
\text { Kaise }\end{array}$ & $\begin{array}{l}\text { alysis. } \\
\text { nalization. }\end{array}$ & & \\
\hline a. Rotation con & ed in 6 & tions. & & & \\
\hline
\end{tabular}

Tabel 1 menunjukkan hasil analisis faktor dengan metode principal component analyses mengesktraksi variable manifest menjadi empat faktor berdasarkan eugin value. Tingkat persentasi kumulatif kontribusi seluruh faktor variable penelitian sebesar $79,140 \%$. Pemberian nama masing-masing faktor sebelumnya sudah ditentukan terlebih 
dahulu mengingat tujuan analisis faktor untuk penelitian ini adalah untuk meyakinkan apakah butir-butir pertanyaan yang diajukan benar-benar mewakili konstruk variable yang
diinginkan.Koefisien kehandalan ditunjukkan oleh koefisien alpha Cronbach yang berkisar antara 0 sampai dengan 1 . Hasil pengujian reliabilitas dapat dilihat pada table 2 .

Table2

Hasil Uji Reliabilitas Pengukuran Variabel Penelitian

\begin{tabular}{lc}
\hline \multicolumn{1}{c}{ Variabel yang diukur } & Koefisien Alpha Cronbach \\
\hline Involvement &, 940 \\
Relevance &, 941 \\
Confussion &, 863 \\
Entertain &, 924 \\
Skeptis & .941 \\
\hline Sumber: data diolah
\end{tabular}

\section{HASIL DAN PEMBAHASAN}

Untuk menjawab pertanyaan penelitian sekaligus mengji hipotesis dalam studi ini, digunakan analisis regresi linier berganda. Hasil ujiregresi ditunjukkan pada tabel 3

Tabel 3

Hasil Analisis Regresi

\begin{tabular}{|c|c|c|c|c|c|c|}
\hline & \multirow[t]{2}{*}{ Model } & \multicolumn{2}{|c|}{$\begin{array}{l}\text { Unstandardized } \\
\text { Coefficients }\end{array}$} & \multirow{2}{*}{$\begin{array}{c}\begin{array}{c}\text { Standardized } \\
\text { Coefficients }\end{array} \\
\text { Beta }\end{array}$} & \multirow[t]{2}{*}{$\mathbf{t}$} & \multirow[t]{2}{*}{ Sig. } \\
\hline & & B & Std. Error & & & \\
\hline \multirow{5}{*}{1} & (Constant) & 22.476 & 2.765 & & 8.130 & .000 \\
\hline & Involvement & -.222 & .090 & -.135 & -2.483 & .014 \\
\hline & Relevance & -.354 & .077 & -.241 & -4.573 & .000 \\
\hline & Confusion & 1.383 & .095 & .616 & 14.562 & .000 \\
\hline & Entertain & .047 & .134 & .014 & .349 & .727 \\
\hline & dent Variable: & & & & & \\
\hline
\end{tabular}

Untuk menguji hipotesis yang pertama"H1: Semakin tinggi keterlibatan konsumen terhadap lingkungan semakin dapat menekan sikap skeptis mereka terhadap iklan hijau" dengan menggunakan uji regresi diperoleh pengaruh yang signifikan (beta= $-, 022, \boldsymbol{p}=0,014)$. Hal ini menunjukkan bahwa semakin tinggi tingkat keterlibatan atau keperdulian konsumen terhadap lingkungan, akan mengurangi sikap skeptis mereka terhadap lingkungan. Hasil ini menunjukkan bahwa hipotesis yang tertama didukung.

Untuk menguji hipotesis yang kedua, "H2: Relevansi menciptakan kepercayaan dalam iklan; kepercayaan tentang iklan akan meminimalkan sikap skeptisisme", diperoleh pengaruh yang signifikan (beta $=-, 354$, $\boldsymbol{p}=0,000)$. Hasil ini menunjukkan bahwa tema iklan hijau yang relevan dapat menguatkan keniatan konsumen untuk membelinya, sekaligus berdampak negative atau mengurangi terhadap sikap skeptis terhadap iklan hijau.

Untuk menguji hipotesis yang ketiga, "H3: Kebingungan menciptakan ketidakjelasan dalam iklan, yang kemudian memperkuat skeptisisme", diperoleh pengaruh yang signifikan (beta $=1.383, p=0,000$ ). Hasil ini menunjukkan bahwa materi iklan yang membingungkan ternyata dapat semakin meningkatkan sikap skeptis konsumen terhadap iklan hijau.

Untuk menguji hipotesis yang keempat, "H4: Semakin banyak tema hiburan dalam iklan akan mengurangi skeptisisme", diperoleh 
pengaruh yang tidak signifikan (beta $=.047$, $\boldsymbol{p}=.727)$. Hasil ini menunjukkan bahwa tema hiburan dalam mempromosikan produk hijau tidak mampu dalam menyakinkan konsumen dan mengurangi sikap skeptis mereka terhadap iklan hijau.

Keterlibatan dapat menunjukkan seberapa besar termotivasinya kita untuk memproses informasi. Dengan semakin meningkatnya keterlibatan, konsumen memiliki motivasi yang lebih besar untuk memperhatikan, memahami, dan mengelaborasi informasi tentang pembelian Keterlibatan konsumen yang tinggi terhadap pelestarian lingkungan, secara sinifikan berdampak pada pengurangan sikap skeptis mereka terhadap iklan hijau. Sikap peduli terhadap lingkungan, adanya keyakinan bahwa kondisi lingkungan mempengaruhi kualitas hidup mereka, kesediaan berkorban untuk melindungi lingkungan, dan kesadaran bahwa aktivitas harian mereka akan berdampak secara langsung pada lingkungan, semakin menepis sikap skeptis terhadap iklan hijau. Mereka akan merasa penting dengan semua informasi yang diberikan terhadap mereka berkaitan dengan pemakaian produk yang dikaitkan dengan pelestarian lingkungan.

Hasil ini telah menguatkan dari beberapa riset mengatakan bahwa ada banyak tipe keterlibatan untuk menerangkan sikap dan behavior intentions konsumen terhadap iklan dan mereka yang diiklankan (Li, 2010). Demikian juga Moore et. al (2000) yang menemukan keterlibatan pengetahuan kelas produk memiliki pengaruh langsung terhadap penerimaan pesan iklan (seperti yang dikutip dariLi (2010). Hasil penelitian ini juga mendukung penelitianyang dilakukan oleh D'Sauza etal. (2007) yang menemukan bahwa individu dengan keterlibatan tinggi akan bersikap positif terhadap iklan hijau, sementara lyang keterlibatannya randah akan semakin meningkatkan sikap skeptis mereka.

Relevansi materi iklan menjadi hal yang dianggap penting oleh khalayak. Relevansi berarti seberapa baik tayangan iklan tersebut mewakili dengan target pesan yang ingin disampaikan (Sala et al. , 2007). Tema iklan yang relevan kan membuat konsumen berfikir bahwa produk tsb. adalah produk yang baik untuk dibeli. Konsumen akan merasa produk yang diiklankan memiliki manfaat yang sama persis dengan pengalaman mereka ketika menggunakannya. Iklan produk ramah lingkungan dirasakan oleh konsemen memiliki manfaat seperti yang mereka perlukan, sehingga timbul keinginan untuk memiliki dan memakainya. Dengan kata lain, melihat iklan produk ramah lingkungan mebuat tema iklan itulah yang menjadi alasan bagi mereka untuk memakai produk ramah lingkungan. Sehingga, dengan tema iklan yang relevan akan menurunkan sikap skeptis konsumen yang menontonnya.

Penelitian ini mendukung studi Chuang, Tsai, Cheng, \& Sun (2009) yang menekankan relevansi iklan dengan bahasa yang tepat. Pemilihan bahasa yang tepatakan dapat meningkatkan relevansi dalam pesan iklan dan mengurangi sikap skeptis mereka. Cowley \& Janus (2004) menekankan relevansi dengan ketepatan informasi yang disampaikan oleh pemasar. kesalahan dalam penyampaian pesan iklan, dapat menyebabkan ketidakpercayaan konsumen. Sementara itu Wang \& Calder (2006) merujuk relevansi dengan keinginan atau kebutuhan pribadi konsumen. Kalau pesan yang disampaikan sesuai dengan kebutuhan mereka saat itu maka konsumen akan menaruh perhatian yang lebih besar pada pesan tersebut, jika tidak, maka informasi yang terlalu banyak dan tidak menyasar pada kebutuhan akan menjadi overload dan meningkatkan sikap skeptis mereka terhadap iklan yang ditontonnya.

Kejelasan penyampaian informasi dalam iklan menjadi hal penting bagi konsumen untuk mengurangi sikap skeptis mereka dengan iklan hijau.Studi ini mendukung beberapa penelitian yang telah dilakukan sebelumnya. Menurut Leek et al.(2009) apabila informasi iklan membuat konsumen bingung dan merasa tidak jelas akan memaksa konsumen untuk mengevaluasi kembali kepercayaan mereka mengenai produk. Sumber yang memunculkan kebingungan ini bisa berasal dari teknologi yang dipakai dalam menyampaikan pesan, informasi ambigu/ klaim produk yang meragukan, informasi yang bertentangan, dan penafsiran yang tidak tepat pada pesan yang mereka terima.

Beberapa ahli perilaku konsumen juga telah mensinyalir kemungkinan awal mula yang menyebabkan konsumen tidak faham dan kemudian bersikap skeptis terhadap iklan hijau.Khuhro et al. (2015) mengemukakan sosio-psikologis adalah penyebab utamanya. Li (2010) menyatakan bahwa kebingungan 
datang dari susunan kata yang dipilih dalam penyampaian pesan iklan.Responden dalam penelitian ini banyak yang menyatakan bahwa mereka kurang memahami isi iklan dengan jelas, pesan terlalu rumit dan membingungkan, dan waktu tayang berlalu begitu cepat sehingga tidak membuat kesan pada diri mereka.

Hasil studi ini yang berbeda dengan beberapa penelitian sebelumnya adalah sifat iklan yang menghibur. Kebanyakan studi sebelumnya menemukan bahwa materi iklan yang bersifat entertain akan menurunkan sikap skeptis konsumen terhadap ikan hijau. Seperti Ozkocak (2011) yang menyatakan bahwa entertainment mengacu pada bagaimana konten dalam iklan dapat memenuhi kebutuhan konsumen akan hiburan, kenikmatan estetika dan pelepasan emosional sehingga dapat menurunkan sikap skeptis pada iklan hijau. Thompson \& Tian (2008).juga menambahkan bahwa entertainment dapat meningkatkan loyalitas dan nilai tambah bagikonsumen. Apalagi temuan Khuhro et. al. (2015) yang menyatakan bahwa iklan yang menghibur adalah salah satu factor terpenting dalam upaya mengurangi sikap skeptic masyarakat Pakistan pada iklan ramah lingkungan.

Hasil studi ini mendukung Moore \& Lutz (2000) yang menyatakan bahwa iklan dipandang hanya sebagai penciptaan gambar dan kurang fokus pada produk itu sendiri (Moore \& Lutz, 2000). Artinya iklan bisa menghibur tetapi pesan belum tentu dapat mereka pahami seutuhnya.Responden dalam studi ini menyatakan bahwa walaupun iklan produk ramah lingkungan menyenangkan untuk ditonton dan dinikmati, cerdas, dan menghibur, akan tetapi belum mampu mengurangi skeptis mereka terhadap iklan produk ramah lingkungan itu sendiri.

Tabel 3 juga menunjukkan bahwa variable confusion adalah variable tertinggi yang menyebabkan tingginya sikap skeptis konsumen terhadap iklan ramah lingkungan. Hal ini mengindikasikan bahwa pengetahuan masyarakat terhadap pentingnya pelestarian lingkungan itu tidak bisa terbentuk hanya dengan iklan produk yang berdurasi sangat cepat.Edukasi secara serius perlu dilakukan oleh pihak yang berkepentingan, terutama dalam rangka meningkatkan pengetahuan mereka terhadap produk ramah lingkungan. Pesan iklan ternyata masih sulit untuk dipahami sehingga tidak dapat memunculkan keinginan mereka untuk membeli produk hijau.

\section{SIMPULAN DAN SARAN}

Beberapa temuan penting yang diperoleh dalam studi ini dapat disimpulkan sebagai berikut:

H1: Semakin tinggi keterlibatan konsumen terhadap lingkungan semakin dapat menekan sikapskeptismerekaterhadapiklanhijautemuan ini mendukung dari temuan sebelumnya ada beberapa riset mengatakan bahwa ada banyak tipe keterlibatan untuk menerangkan sikap dan behavior intentions konsumen terhadap iklan dan mereka yang diiklankan (Li,2010) Faktor keterlibatan konsumen memiliki pengaruh langsung maupun tidak langsung pada sikap terhadap iklan. Misalnya, Moore et al. (2000) berpendapat bahwa keterlibatan pengetahuan kelas produk memiliki pengaruh langsung terhadap penerimaan pesan iklan seperti yang dikutip dari Li (2010).

H2: Relevansi menciptakan kepercayaan dalam iklan; kepercayaan tentang iklan akan meminimalkan sikap skeptisisme temuan ini didukung oleh temuan sebelumnya yaitu dalam hal ini relevansi berarti seberapa baik tayangan iklan tersebut mewakili dengan target pesan yang ingin disampaikan (Sala et al. , 2007). Pemilihan terminologi yang tepat dapat membuat dampak yang lebih baik pada iklan ketika tingkat pengetahuan konsumen tinggi. Bahkan pilihan terminologi ini menjadi simbol untuk keaslian dan keberhasilan dalam tayangan iklan. Ketertarikan konsumen karena bahasa yang tepat ini pada saatnya akan dapat meningkatkan relevansi dalam pesan iklan dan mengurangi sikap skeptis mereka (Chuang, Tsai, Cheng, \& Sun, 2009). Sedangkan Apabila target iklan adalah individu yang berpendidikan, relevansi pesan iklan harus ditingkatkan sehingga akan membuat konsentrasi individual yang lebih besar dalam menangkap pesan (Pham 1998). Konsumen dengan pengetahuan yang tinggi dapat menilai relevansi produk atau jasa dengan kebutuhan dan keinginan mereka. Apabila terjadi kesalahan informasi yang dilakukan oleh pemasar dalam penyampaian pesan iklan, dapat menyebabkan ketidakpercayaan 
konsumen (Cowley \& Janus, 2004). Bila pesan memiliki relevansi dengan keinginan atau kebutuhan pribadi mereka, konsumen akan menaruh perhatian yang lebih besar pada pesan tersebut, namun pada saat yang sama jika lalulintas pesan sangat tinggi (overload) dan kurang menyentuh dengan kebutuhan pribadi mereka, dapat mengakibatkan dampak negatif pada iklan (Wang \& Calder, 2006).

H3: Kebingungan menciptakan ketidakjelasan dalam iklan, yang kemudian memperkuat skeptisisme temuan ini didukung olrh penelitian sebelumnya yaitu dalam proses periklanan, variabel ambiguitas menjadi hal yang penting. Kuhro et al. (2015) telah membahas bahwa sosio-psikologis adalah faktor yang memotivasi pemirsa televisi untuk melihat iklan. Kebingungan dapat berasal dari merek dagang ketika merek yang diiklankan; kebingungan initerjadi atas dasar asosiasi. Asosiasi dibagi dalam tiga kategori, kebingungan langsung, kebingungan tidak langsung, atau kebingungan murni (Li, 2010). Kebingungan mungkin datang dari susunan kata yang dipilih dalam penyampaian pesan iklan (LeBlanc \& Muise, 1985). Terminologi juga dapat menciptakan kebingungan dalam iklan, biasanya terjadi ketika pengakuan produk (akreditasi) ditampilkan dalam iklan (Brinkmann, Czaske, \& Bosch, 2003). Sertifikasi yang berkaitan dengan kandunganbahan baku produk dan akreditasi bahan yang dikeluarkan produsen. Kebingungan konseptual sering merasuki pemikiran dan mendorong over-generalisasi. Hal ini dapat menjadikankonsumen menjadi lebih menyederhanakan suatu informasi (LeBlanc \& Muise, 1985).

H4: Semakin banyak tema hiburan dalam iklan akan mengurangi skeptisisme temuan ini tidak didukung oleh temuan sebelumnya yaitu , Entertainment mengacu pada bagaimana konten dalam iklan dapat memenuhi kebutuhan konsumen akan hiburan, kenikmatan estetika dan pelepasan emosional (Ozkocak,2011). Kesenangan dihubungkan dengan periklanan yang memainkan peranan yangsangat besar bagi seluruh sikap mereka terhadap iklan (Thompson \& Tian, 2008).Entertainment dapat meningkatkan loyalitas konsumen dannilai tambah bagikonsumen. Emosi seseorang adalah bagian yang pasti ada dari perilaku dan kemampuan kognitif. Para peneliti mengaitkan emosi dengan pengambilan keputusan. Mereka menemukan bahwa emosi membantu untuk memahami suatu pesan. Ada lima emosi utama, pertama, kemarahan, kedua, ketakutan, ketiga, jijik, keempat, kebahagiaan, kelima, kesedihan. Pemicu emosiditayangkan kepada pemirsa untuk hiburan (Salem \& Rauterberg, 2005). Dalam iklan populer, seruan/ajakan digunakan untuk memberikan rasa tertentu pada pelanggan. Ketika pemasar berniat untuk menangkap pasar umum yang lebihbesar, dalam hal ini, tema hiburan digunakan untuk pelanggan biasa. Sementara itu cita rasa seni dan kompleksitas yang lebih tinggi digunakan untuk pelanggan profesional yang memiliki daya fikir yang kritis(Kuhro, et al.,2015). Suatu kenyataan yang harus dipertimbangkan para pemasar adalah bahwa penikmat iklan adalah di kalangan anak-anak. Mereka biasanya mendapatkan pesan iklan dalam bentuk hiburan. Anak-anak terutama yang sudah bisa berfikir, terbukti lebih tertarik dengan pesan iklan konsumsi dalam bentuk hiburan. Namun demikian, hal ini juga dapat menyebabkan ancaman bahwa iklan dipandang hanya sebagai penciptaan gambar dan kurang fokus pada produk itu sendiri (Moore \& Lutz, 2000). Artinya iklan bisa menghibur tetapi pesan belum tentu dapat mereka pahami seutuhnya. Menurut Thompson \& Tian (2008), mitologi iklan mengandung hiburan dalam berbagai bentuk hiburan yang digunakan oleh pemasar seperti konser, olahraga, drum, film, dan narasi. Pemasar fokus pada pesan bertema hiburan sehingga konsumen lebih banyak mendapatkan iklan dengan tema hiburan ini. Di Amerika 8,5 persen dari total pendapatan mereka dihabiskan untuk iklan dengan tema hiburan (Salem \& Rauterberg, 2005).

\section{Keterlibatan konsumen dalam} lingkungan, relevansi dan kejelasan materi iklan hijau akan dapat mengurangi sikap skeptis konsumen terhadap iklan. Tema dan tampilan iklan yang menghibur, belum dapat mengurangi sikap skeptis mereka. Faktor terpenting yang dapat mengurangi sikap skeptis terhadap iklan hijau adalah pemilihan informasi yang jelas, bersifat edukatif, dan lugas serta tidak membingungkan konsumen Keterbatasan Penelitian 
1. Studi ini bersifat survey, sehingga peneliti tidak dapat mengontrol tongkat keberagaman informasi iklan hijau yang ditonton oleh responden

2. Penggalian data bersifat persepsi responden yang mungkin terjadi bias dengan keadaan mereka yang sebenarnya tentang tanggapan mereka terhadap iklan hijau

3. Penelitian ini tidak membatasi produk tertentu dan industry tertentu, sehingga tayangan iklan yang dinilai mungkin berbeda antar responden

\section{Saran untuk penelitian yang akan datang,}

1. Tema iklan hijau ini akan lebih baik kalau menggunakan desain eksperimen, sehingga peneliti dapat mengontrol keseragaman iklan yang dilihat oleh responden

2. Pengamatan langsung dan wawancara terbuka dengan responden akan dapat mengurangi bias informasi, sehingga lebih dapat menggambarkan keadaan yang dirasakan responden sebenarnya

3. Penelitian yad perlu membatasi produk tertentu dengan tayangan iklan tertentu, sehingga persespsi semua responden pada waktu melakukan penilaian adalah pada iklan yang sama

\section{Implikasi Manajerial}

Hasil penelitian ini memberikan masukan bagi produsen produk ramah lingkungan dalam menginformasikan produk mereka pada masyarakat:

1. Para pemasaran harus semakin menyadari bahwa iklan adalah sarana yang powerfull bagi mereka untuk menginformasikan produk hijau kepada konsumen. Mendisain iklan yang baik akan berbanding lurus dengan kelancaran penjualan, demikian pula yang terjadi sebaliknya

2. Merancang iklan hijau dengan tema yang lebih edukatif, infomatif, dan familiar sehingga infomrasi yang disampaikan mudah difahami bagi khalayak dengan tingkat pendidikan yang berbeda

3. Memilih tema iklan yang relevan, sehingga menimbulkan peningkatan keniatan masyarakat untuk membeli iklan hijau

4. Perusahaan bisa menggunakan dana CSR mereka untuk memberikan edukasi pada masyarakattentang pentingnyapelestarian lingkungan dengan mengkonsumsi produk ramah lingkungan. Keterlibatan dan tingkat keperdulian masyarkat pada akhirnya akan semakin meningkatkan niat beli mereka pada produk hijau.

\section{PERSANTUNAN}

Hasil karya yang sederhana ini tidak terlepas dari masukan reviewerdan bapak ibu dosen FEB UMS yang bersedia menjadi rekan diskusi sekaligus ikut hadir dalam pemaparan hasil penelitian. Peneliti sangat menghargai, memperhatikan, dan mengucapkan terimakasih terhadap semua pihak yang ikut berperan dalam penyempurnaan penelitian ini. Secara khusus, kepada Dikti yang telah membantu mendanai penelitian ini sd selesai melalui skim hibah bersaing.

\section{DAFTAR KEPUSTAKAAN}

Albayrak, T., Caber, M., \& Moutinho, L (2011).The Influence of Skepticism on Green Purchase Behavior.International Journal of Business and Social Science, 2(13), 189-197.

Brinkmann, K., Czaske, M., \& Bosch, W. (2003). Certification of reference materials and accreditation of reference material producers: Questionable terminology leads to confusion. Accreditation and Quality Assurance: Journal for Quality, Comparability and Reliability in Chemical Measurement, 8(9), 408-412.

Chen, Y.S., \& Chang, C.H. (2012). Enhance Green Purchase Intentions: The Roles of Green Perceived Value, Green Perceived Risk, and Green Trust. Management Decision, 50(3): 502-520.

Chuang, S. C., Tsai, C. C., Cheng, Y. H., \& Sun, Y. C. (2009). The effect of terminologies on attitudes toward advertisements and 
brands: Consumer product knowledge as a moderator. Journal of Business and Psychology, 24(4), 485-491.

Cowley, E., \& Janus, E. (2004). Not necessarily better, but certainly different: A limit to the advertising misinformation effect on memory. Journal of consumer research, 31(1), 229-235.

D’Souza, C., Taghian, M. \& Khosla, R. (2007). Examination of environmental beliefs and its impact on the influence of price, quality and demographic characteristics with respect to green purchase intention. Journal of Targeting, Measurement and Analysis for Marketing, 15, 69-78

Kapferer, J-N.\& Laurent, G. (1993). Further evidence on the consumer involvement profile: fiveantecedents of involvement. Journal of Marketing Research, 22 (February), 41-53.

Khuhro, Quraishi, Humayon, Yasin dan Javed (2015). Relevance, Confusion,Entertainment and Skepticism towards advertising International Journal of Economics, Commerce and Management, United Kingdom. Vol. III, Issue 3, March 2015

Lastovicka, L. J. (1983). Convergent and Discriminant Validity of Television Commercial Rating Scales.Journal of Advertising, 12(2), 14-23.

LeBlanc, R. S., \& Muise, J. G. (1985). Alphabetic confusion: A clarification. Attention, Perception, \& Psychophysics, 37(6), 588-591.

Leek, J. K., Lee, W.N. (2009). Country-oforigin effects on consumer product evaluation andpurchase intention: The role of objective versus subjective knowledge. Journal ofInternational Consumer Marketing 21 (2), 137-151.

Li, Y. (2010). Analysis on the impact of the "Dilution Theory" on ruling of trademark cases.Frontiers of Law in China, 5(1), 27-55.
Mainieri, T., Barnett, E. G., Valdero, T. R., Unipan, J. B., \& Oskamp, S. (1997). Greenbuying: The influence of environmental concern on consumer behavior. Journalof Social Psychology, 137(2), 189-204.

Mitchell, A.A. (2004). The dimensions of advertising involvement. In: Monroe, B.K. (Ed.),Advances in Consumer Research 8, Provo UT: Association for Consumer Research, pp.25-30.

Moore, E. S., \& Lutz, R. J. (2000). Children, advertising, and product experiences: A multimethod inquiry. Journal of consumer research, 27(1), 31-48.

Mostafa, M. M., (2007). A hierarchical analysis of the green consciousness of theEgyption consumer.Psychology and Marketing, 24, 445-473

Obermiller, C., \& Eric, R. S. (1998). Development of a Scale to Assess Consumer Skepticism toward Advertising.Journal of Consumer Psychology, 7(2), 159-186.

Obermiller, C., \& Spangenberg, E. R. (2000).On the Origin and Distinctness of Skepticism toward Advertising. Marketing Letters, 11(4), 311-322.

Obermiller, C., Spangenberg, E., \& MacLachlan, D. L. (2005). Ad skepticism: The consequences of disbelief. Journal of Advertising, 34(3), 7-17.

Ozkocak, L. L. (2011). A Content Analysis: Environment Themes and Tools in Newspapers Advertisements. Online Journal of Communication and Media Technologies, 1(3):2

Pham, M. T. (1998). Representativeness, relevance, and the use of feelings in decision making.Journal of consumer research, 25(2), 144-159.

Research, A. (2011). The marketing and advertising Retrieved 01/10/2011, 2011, from http://abiresearch.com/news 
Russell, C. A. (2007). Advertainment: Matter When Advertising a Green Fusing Advertising and Entertainment. Product?"Journal of Advertising, 24 Ann Arbor, Mich.: University of (Summer),

Michigan Yaffe Center for Persuasive Communication.

Salem, B., \& Rauterberg, M. (2005). Power, death and love: a trilogy for entertainment. Entertainment Computing-ICEC 2005, 279-290.

Sala, M., Partridge, K., Jacobson, L., \& Begole, J. (2007).An exploration into activity-informed physical advertising using pest.Pervasive Computing, 73-90.

Solomon, M. R., (2009). Consumer Behaviour: Buying, Having, and Being, Prentice Hall

Schuhwerk, M., and R. Lefkokk-Hagius (1995), “Green or Not- Green? Does Type of Appeal

$45-55$.

Thompson, C., \& Tian, K. (2008). Reconstructing the south: How commercial myths compete for identity value through the ideological shaping of popular memories and counter memories.Journal of consumer research, 34(5), 595-613.

Wang, J., \& Calder, B. J. (2006).Media transportation and advertising.Journal of consumer research, 33(2), 151-162.

Waskito \& Sujadi (2013). Model peningkatan pembelian konsumen terhadap produk hijau. Benefit, 17, 12-17 